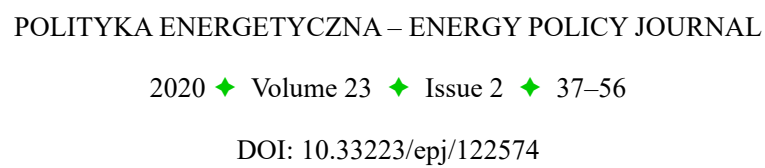

\title{
CSR initiatives in an integrated energy entity - monetary dimension
}

ABSTRACT: The subject of this article concerns the growing issue of implementing the concept of social responsibility in the activities of integrated energy entities. This work includes the performance of a budgetary analysis of the national leading company, in terms of expenses associated with corporate social responsibility (CSR). The article presents the analysis of source literature, as well as identifies stakeholder activities. The introduction includes an explanation of the concept of CSR, its global approach along with the justification for the need to implement the concept of CSR in the strategy of industry entities. The following were used, among others, to perform the research: elements of financial and non-financial reporting, i.e. reports of a vertically integrated energy company - Capital Group Polska Grupa Energetyczna SA, over the years 2013-2017. The data obtained from distributed sources were used. The company's activities in social and environmental directions were identified, and the stakeholder groups of these initiatives were determined. The main purpose of this article was to estimate the level of expenditure associated with CSR in the context of the company's general budget. The article emphasizes the role of the PGE Foundation as a recognizable point of company activity in the scope of CSR (the participation of individual group companies in financing the foundation was presented). The analysis of CSR expenditure included:

Corresponding Author: Justyna Woźniak; e-mail: justyna.wozniak@pwr.edu.pl

1 Wrocław University of Science and Technology, Wrocław, Poland; ORCID iD: 0000-0002-8139-8529; e-mail: justyna.wozniak@pwr.edu.pl

${ }^{2}$ Graduate of Faculty of Geoengineering, Mining and Geology, Wrocław University of Science and Technology, Wrocław, Poland; ORCID iD: 0000-0002-4251-0039; e-mail: jszew@icloud.com

2020. The Author(s). This is an open-access article distributed under the terms of the Creative Commons Attribution-ShareAlike International License (CC BY-SA 4.0, http://creativecommons.org/licenses/by-sa/4.0/), which permits use, distribution, and reproduction in any medium, provided that the Article is properly cited. 
the amount of taxes paid, costs of employee benefits and assets of the social services fund, and environmental costs.

KeYwORDs: Corporate Social Responsibility (CSR), budgetary analysis, integrated mining and energy entity

\section{Introduction}

In accordance with the main assumption, Corporate Social Responsibility (CSR) can be characterized as an area concerning the internal regulations of an organization, which take international standards, applicable regulations of the law, principles of ethics and standards as a positive impact on society (widely understood group of stakeholders) and the natural environment into account (Woźniak 2019). CSR dates back to the turn of $19^{\text {th }}$ and $20^{\text {th }}$ century, when it was perceived as the concern of wealthy people for the poorer in contemporary society. The current manner of CSR perception was initiated in the United States, while a little later it also appeared in the United Kingdom, where the "Social Responsibilities of the Businessman" was published by H. Bowen (1953). It described the need to take problems functioning in the company's surroundings into account. According to the European Commission's definition, which was included in the Green Paper (2001), CSR means the responsibility of enterprises for their impact on society. Among others, the following were created from 1989 to 2010: SA 8000, ISO 14001, AA 1000, ISO 26000. CSR activities include: combining the entity's strategy (among others, the management of: risk, crisis situations, customer relations or supply chain), human capital (management of human resources and surrounding elements) and environmental aspects (among others: minimizing the impact of operational activities) included in the reporting (in socio-environmental scope aimed at integrated reporting) (Woźniak 2019). In the work of (Kemp et al. 2012), the concept of CSR appears as a relational process, which develops organizational knowledge in order to improve the social result, where at an operational level the staff participates in the dialogical form of internal responsibility. In relation to the mining industry, Govindan et al. (2014) or Jonek-Kowalska (2018) indicate CSR activities as the development of relations with internal and external stakeholders. In the context of development and popularization of Corporate Social Responsibility in Poland, the so-called RESPECT Index (RI) (Witek-Crabb 2019) is of big importance. In 2009, this index of environmentally and socially responsible companies was established in Warsaw on the Warsaw Stock Exchange. Its name is an acronym of the words that that define the merits of CSR: Responsibility, Ecology, Sustainability, Participation, Environment, Community and Transparency. The purpose is to select companies that are managed responsibly and in a sustainable manner, further emphasizing their investment attractiveness. Currently (as of the $12^{\text {th }}$ edition of the RI, which is applicable until December 2019), this index includes 31 companies listed on the Warsaw Stock Exchange. They are characterized by high standards in 
relations with the investors, in the environmental, social and employee scope, as well as in the sphere of information and corporate governance. These companies include entities from the mining and related industries, i.e. Energa SA, JSW SA, KGHM Polska Miedź SA, LW Bogdanka SA, PGE SA (Polska Grupa Energetyczna), PGNiG SA and PKN Orlen, TAURON PE, SA, Zespół Elektrociepłowni Wrocławskich Kogeneracja SA (www.respectindex.pl). This article focuses on the vertically integrated capital group, i.e. PGE SA, which has been creating the value of the RI portfolio at the level of approx. 7-8\% continuously since 2011. Moreover, the article analyzes the level of social and environmental expenses within the CSR, showing the financing of stakeholder initiatives by the analyzed entity. According to the literature, the CSR expenses are largely driven by political and social factors, treated as an investment as well as source of innovation (Krawczyk 2019), and not driven by economic reasons. The mandatory disclosure of CSR practices changes the behavior of companies and generates a positive impact on society at the expense of shareholders (Chen et al. 2018). The work of (Lodhia and Hess 2014) indicates the importance of partnerships between NGOs and the improvement of good practices in the mining industry towards non-financial reporting, which evolves at a slow pace. According to the works of Polish authors (Bluszcz and Kijewska 2015; Jarosławska-Sobór 2015; Bogacz and Migza 2016; Manowska et al. 2017; Pactwa and Woźniak 2017; Bąk and Michalak 2018; Hąbek et al. 2019; Jonek-Kowalska 2019; Pactwa 2019a, 2019b; Woźniak 2019), Polish companies from mining and related industries are learning to implement the CSR concept and the principles of sustainable development in their strategy of operation. International works demonstrate that the mining industry entities were one of the first to publish independent environmental reports and to adopt voluntary codes of conduct in the scope of environmental management (Hamann 2003; Jenkins and Yakovleva 2006; Mutti et al. 2012).

\section{Integrated energy entity - the case of PGE SA}

The PGE SA Capital Group is a vertically integrated company that has its own fuel resources (lignite) and the distribution network. This company is engaged in the active policy of supporting renewable energy sources, through the generation of energy from hydroelectric power stations, wind farms and biomass as well as fossil fuels. Retail sales constitute the last segment of the power industry activity. Approx. $40 \%$ of the market is controlled by PGE during the analyzed period (Fig. 1). It is one of the biggest enterprises in the electrical power sector in Poland, in terms of (among others) financial results or stable employment issues (Table 3). The energy market in Poland is shaped by five main energy groups. Among them, the leader is PGE, which produced $56.8 \mathrm{TWh}$ of electricity in 2017. The remaining companies include: ENEA $21 \mathrm{TWh}$, Tauron 18.4 TWh, ZE PAK 8.4 TWh and Energa 4.3 TWh, whose share on the market has remained at a similar level over the past several years. 


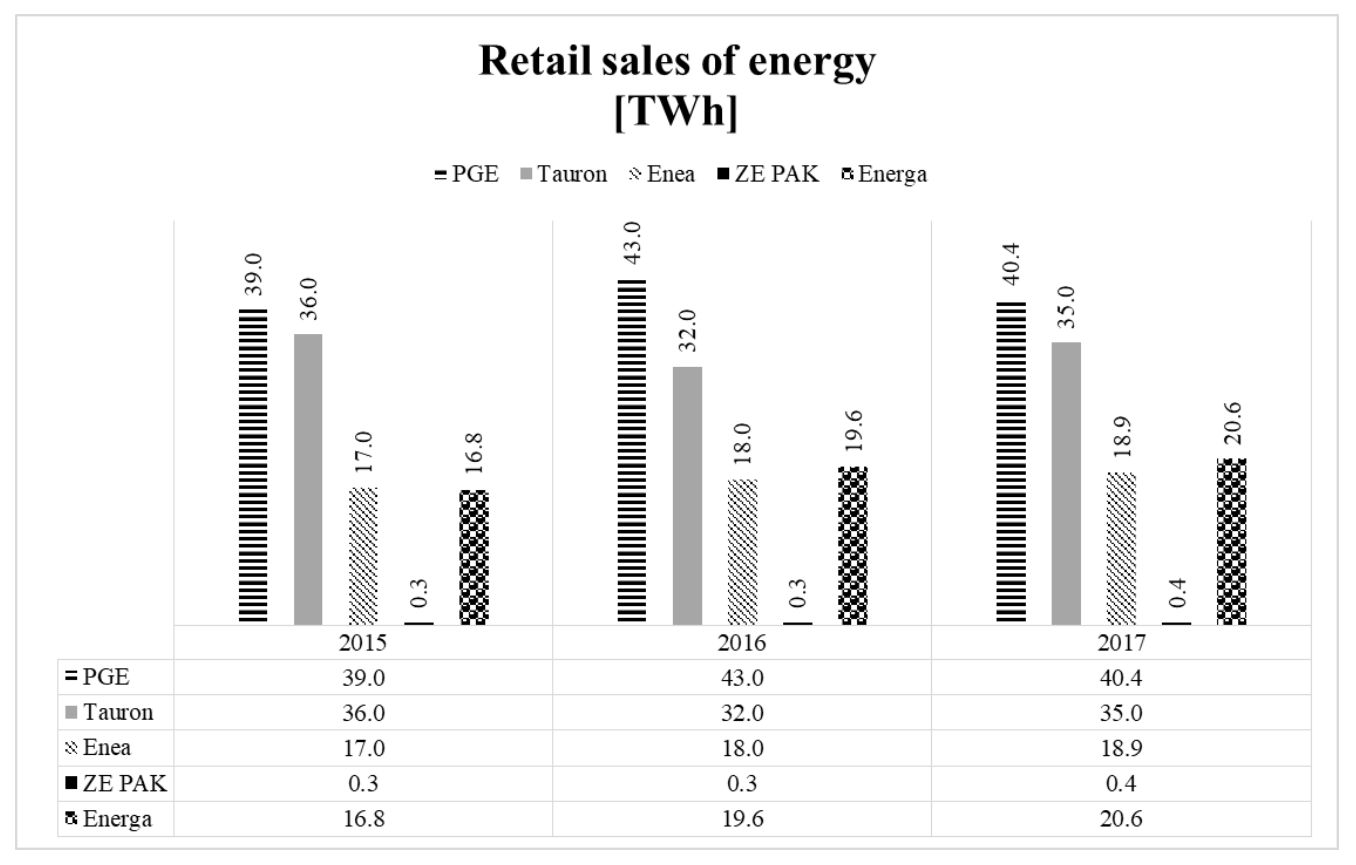

Fig. 1. Retail sales of energy in Poland, own study based on companies' reports (Reports: PGE, Tauron, Enea, ZE PAK, Energa)

Rys. 1. Sprzedaż detaliczna energii w Polsce

Taking the scope of conducted activities into account, the group is a guarantee of the stable supply of electricity to its customers, making every effort in order to minimize the emission of pollutants. Since 2011, PGE SA has been a part of the collective portfolio of the first national index of socially responsible companies - RESPECT Index.

\section{Stakeholders and CSR initiatives}

The identification of the entity's stakeholders and activities associated with them. According to the Freeman's definition (1984), stakeholders consist of "any group or natural person, who is able to have influence or have influence on the achievement of the organization's goals" (Viveros 2017). In this sense, the interest in the research concerning stakeholders and corporate social has increased (Clarkson 1995; Dobele et al. 2014; Morsing and Schultz 2006; Mutti et al. 2012; Dong et al. 2014; Viveros 2016; Yakovleva and Vazquez-Brust 2012; Alves et al. 2019; Que et al. 2018; Que et al.2019), providing evidence for the impact of such groups on corporate practices. The com- 
panies, which consider themselves socially responsible, interact with the stakeholders in order to meet their expectations. Stakeholders theory indicates that the existence and continuity of a company requires the support and approval of individual groups of stakeholders (Devenin and Bianchi 2018). Each individual group of stakeholders is extremely important and a mature approach involving such groups at various levels of communication allows them to achieve the ultimate success (www.odpowiedzialnybiznes.pl). The stakeholders can be divided according to a number of criteria. Taking the various characteristics of relations occurring between the company and the stakeholders into account, consubstantial stakeholders are distinguished, without whom the organization could not exist. These are entities working in the enterprise or investing their capital, i.e. employees, shareholders and owners. The subsequent group are contractual stakeholders, which are bound by a formal contract with the company, e.g. suppliers, customers and business partners. The last group referring to the nature of the relation are the so-called context stakeholders, which are not directly associated with the company, but at the same time have a huge impact on the public opinion. They can include social organizations, governmental organizations, as well as local communities, whose goal is the common good. In relation to the PGE group, whose scope of activities is very broad and may be associated with social unrest, the stakeholders require the company to undertake campaigns associated with the environment and safety. If the company implements activities, which are expected by the interested parties (contextual stakeholders), such a company can count on positive reception and acceptance on the market (Wachowiak 2012; Woźniak and Jurczyk 2019). The next criterion that is taken into account during this division is the place of their occurrence. In this case, the literature divides the stakeholders into internal members of organizations influencing and participating in projects implemented by the company (employees, management, shareholders) and external - non-members of the organization, who, however, significantly affect the overall assessment (customers, local community, state and local authorities). They are of a more representative nature (Anuszkiewicz and Marona 2012).

In accordance with the above-mentioned definition, the following can be recognized as the main stakeholders of PGE customers, employees, shareholders, the community, local authorities, as well as the natural environment - the so-called silent stakeholder. Due to the fact that this company is characterized by a large degradation effect on the natural environment, it conducts many activities aimed at counteracting this phenomenon. The silent stakeholder is represented by institutions, which influence the enterprises and spur them into action (www.odpowiedzialnybiznes.pl). The Group establishes and supports many undertakings that engage employees, customers, the local community, as well as the natural environment. Among others, the employees can count on the "Job Rotations" Project, which was awarded in 2016 by the Responsible Business Forum (FOB) (www.odpowiedzialnybiznes.pl), which is an organization supporting the Polish CSR. The FOB participates and organizes many key initiatives for the development of social responsibility in Poland. This project focuses on connecting employees from various areas of activities, in order to exchange experience and knowledge. The internal knowledge base for employees, the so-called Wiki PGE, which was created in order to broaden the horizons of employees on the subject of generally understood power engineering is also important. Employees have the possibility to share their knowledge, as well as to obtain information from it. 
Moreover, it includes a rating and comment system, which allows the data to be authenticated. In the aspect of customers, the group creates programs that facilitate their life, the example of which is the "Counteracting Energy Poverty" campaign that focuses on the poor. The company implements subsidies in regard to the bills for hot water and heating of apartments. In the case of service recipients, the training of the customer service department in sign language, which was created for PGE employees is also worth mentioning. This allows communication barriers to be overcome and reduce social inequalities. In 2016, the training was conducted at the largest Customer Service Offices within a company that is a part of the PGE structure, i.e. PGE Obrót. While analyzing the social activities within the CSR framework, the following can be distinguished: educational campaigns, charity and philanthropic activities, education of children and youth, as well as cooperation with universities. One of the most interesting projects is the "Atom for Science", which focuses on the development of nuclear energy, aimed at students, graduates and academic lecturers. Moreover, as part of the project, the lectures for the youth and participants of the University of the Third Age are also implemented. In the context of natural environment, campaigns in the following areas can be distinguished: biodiversity, ecological education, eco-efficiency, renewable energy sources, pro-environmental programs and recycling. One of the major undertakings consisted of the construction of a flue gas desulphurization installation, which was implemented at the Combined Heat and Power Plant Bydgoszcz, belonging to PGE GiEK SA - PGE Górnictwo i Energetyka Konwencjonalna SA. This allowed dust and sulphur dioxide emissions to be significantly reduced, by adapting the devices to the environmental requirements of the Directive of the European Parliament on industrial emissions.

While verifying the socio-environmental information and initiatives undertaken by PGE, these initiatives were divided in terms of stakeholders in the given functional area. Four large groups of stakeholders were distinguished, i.e. employees, customers, local community and natural environment, and individual activities implemented the entity in the years 2014-2017 were assigned to them. The summary is presented in Table 1.

TABLE 1. List of the company's good practices in the scope of stakeholders

TABELA 1. Zestawienie dobrych praktyk spółki z interesariuszami

\begin{tabular}{|c|c|c|}
\hline Stakeholders & Activities implemented by the company & Functional Area \\
\hline 1 & 2 & 3 \\
\hline \multirow{7}{*}{ Employees } & $\begin{array}{l}\text { System for identification of safe behaviors among the } \\
\text { subcontractors' employees }\end{array}$ & \multirow{2}{*}{ Safety in the workplace } \\
\hline & $\begin{array}{l}\text { Occupational health and safety reference tool for external } \\
\text { companies in Polish, English and Ukrainian version }\end{array}$ & \\
\hline & Educational board game for the PGE employees & Recruitment and adaptation \\
\hline & „Job Rotations” Project & \multirow{2}{*}{ Trainings and development } \\
\hline & Wiki PGE & \\
\hline & Safety above all else & Safety in the workplace \\
\hline & Employee volunteering service „We help” & Employee volunteering service \\
\hline
\end{tabular}




\begin{tabular}{|c|c|c|}
\hline 1 & 2 & 3 \\
\hline \multirow{6}{*}{ Customers } & Counteracting energy poverty & \multirow{2}{*}{ Facilitation for customers } \\
\hline & Smart energy measurement system METEUS & \\
\hline & Service Cable Lines & \multirow[b]{2}{*}{$\begin{array}{l}\text { Availability of products and } \\
\text { services }\end{array}$} \\
\hline & $\begin{array}{l}\text { Training of customer service in sign language for PGE } \\
\text { employees }\end{array}$ & \\
\hline & „Verify who sells you energy” & \multirow{2}{*}{ Education of consumers } \\
\hline & „Be enlightened” & \\
\hline \multirow{14}{*}{ Local community } & „Awareness on the road" & Educational action \\
\hline & Honorary blood donors in PGE GiEK & \multirow{4}{*}{$\begin{array}{l}\text { Charity and philanthropic } \\
\text { activities }\end{array}$} \\
\hline & Experts on the road for orphanages & \\
\hline & SOS Philippines campaign - The Gift of Home & \\
\hline & Energetic Schoolbag & \\
\hline & Cinema on bikes & \multirow{8}{*}{ Education of children and youth } \\
\hline & Safe and economical use of energy & \\
\hline & Water Machines Tournament & \\
\hline & Safe Energy & \\
\hline & "Theater energy" workshops & \\
\hline & Knowledge about energy for the youngest & \\
\hline & Electricity - my safe friend & \\
\hline & „Mr. Lighting” and „Experiments” & \\
\hline & Atom for Science & Cooperation with universities \\
\hline \multirow{11}{*}{$\begin{array}{l}\text { Natural } \\
\text { environment }\end{array}$} & Reintroduction of peregrine falcons & Biodiversity \\
\hline & Forest full of energy & \multirow{3}{*}{ Ecological education } \\
\hline & „Upstream holidays - we discover places full of energy” & \\
\hline & Ecological mural over Solina & \\
\hline & Green office of PGE & Eco-office \\
\hline & „Naturally Energy” & Eco-efficiency \\
\hline & First photovoltaic power plant & \multirow{2}{*}{ Renewable energy sources } \\
\hline & Eco Energy & \\
\hline & „We care about bird protection” & \multirow{2}{*}{ Pro-environmental program } \\
\hline & Clean air in Bydgoszcz & \\
\hline & Management of combustion by-products in PGE & Recycling \\
\hline
\end{tabular}

Source: Szewczak 2019. 


\section{CSR expenditure of the integrated energy entity}

PGE SA chose the PGE Foundation to be the executive pillar of social responsibility and it has been operating since 2011 supporting the local community. This corresponds to the growing global tendency to engage in non-profit partnerships (Eweje and Palakshappa 2009; Jamali and Keshishian 2009; Arond et al. 2019). The PGE Foundation is a kind of flagship. The scope of foundation's activities is very wide. Starting from social assistance and charity activity, as well as broadly defined attitudes counteracting social pathologies, they also include issues associated with national minorities. Moreover, the activities aimed at intensifying economic development, entrepreneurship, as well as improving the values of education and science are carried out. Environmental issues are also included in the scope of the PGE Foundation, as it implements initiatives covering the issues of animal protection, natural heritage and ecology. In addition, this organization provides help both in the country and abroad to the victims of natural disasters and catastrophes. In order to be able to implement the above-mentioned objectives, the financial resources are necessary, which it obtains (among others) from the members of GK PGE SA. During the analysis, some regularity was noticed. Many initiatives, mainly social, were financially supported as part of the PGE Foundation's activity. After the analysis of the percentage level of support for the foundation's budget (Fig. 2) in the years 2013-2017, it is clear which companies forming the entire group's business line support the foundation's activities to the greatest extent. PGE PGiEK SA, which is responsible for the extraction of energy resources and electricity generation, is the main financial pillar of the parent company in the group (next to PGE SA).

In 2013 and 2014, the sum of the foundation's subsidies did not exceed EUR 1 million, while in the following year its significant increase was noticed, mainly due to PGE GiEK, which in 2015 allocated EUR 1 million for the implementation of projects in the scope of the PGE Foundation. The next year brought a significant drop in the subsidies and complete resignation of PGE SA. In 2016, the sum of subsidies was the lowest in the entire analyzed period. This resulted from a decrease in the level of subsidies from PGE GiEK and the absence of PGE SA. 2017 was similar to the initial years of the analyzed period and only the total amount of subsidies from all companies increased, which exceeded EUR 1 million.

While analyzing Table 2, it can be noticed that in the years 2013, 2014 and 2017, the main investors accounted for 70-80\% of the finances allocated for support. In 2015, the level of funds flowing from PGE GiEK increased from $35 \%$ in 2014 to $60 \%$, while the funds from PGE SA decreased from $35 \%$ to $20 \%$. The next year brought complete resignation of PGE SA from subsidies, while the level of sponsorship by PGE Dystrybucja increased from 9\% in 2015 to almost $20 \%$ (Table 2). This resulted from a decrease in the total amount of the subsidy, because it should be emphasized that throughout the entire analyzed period, PGE Dystrybucja subsidized the foundation at the level of EUR 120,000-140,000 on an annual basis. Therefore, the support of other companies was symbolic, however also important. 
TABLE 2. Percentage representation of the share of individual companies in the financing of the foundation

TABELA 2. Procentowe przedstawienie udziału poszczególnych spółek w finansowaniu fundacji

\begin{tabular}{|l|c|c|c|c|c|}
\hline \multicolumn{5}{|c|}{ Percentage share of companies in financing of the foundation } \\
\hline & 2013 & 2014 & 2015 & 2016 & 2017 \\
\hline PGE SA & $36.2 \%$ & $35.6 \%$ & $20.4 \%$ & $0.0 \%$ & $40.9 \%$ \\
\hline PGE Dystrybucja & $15.1 \%$ & $15.2 \%$ & $9.1 \%$ & $19.2 \%$ & $11.4 \%$ \\
\hline PGE Obrót SA & $5.4 \%$ & $5.3 \%$ & $3.0 \%$ & $7.7 \%$ & $4.5 \%$ \\
\hline PGE EJ1 Sp. z o. o. & $5.4 \%$ & $5.3 \%$ & $4.5 \%$ & $11.5 \%$ & $6.8 \%$ \\
\hline PGE GiEK SA & $36.1 \%$ & $35.6 \%$ & $60.3 \%$ & $57.5 \%$ & $34.1 \%$ \\
\hline PGE Energia Odnawialna SA & $1.9 \%$ & $1.4 \%$ & $1.2 \%$ & $3.3 \%$ & $1.7 \%$ \\
\hline Exatel SA & $0.0 \%$ & $1.1 \%$ & $0.6 \%$ & $0.0 \%$ & $0.0 \%$ \\
\hline PGE Energia Natury Sp. z o. o. & $0.0 \%$ & $0.0 \%$ & $0.5 \%$ & $0.0 \%$ & $0.0 \%$ \\
\hline PGE Systemy SA & $0.0 \%$ & $0.0 \%$ & $0.3 \%$ & $0.8 \%$ & $0.5 \%$ \\
\hline Others & $0.0 \%$ & $0.6 \%$ & $0.0 \%$ & $0.0 \%$ & $0.0 \%$ \\
\hline
\end{tabular}

Source: own study based on the foundation's reports from the years 2013-2017.

\section{Taxes as a support of the local environment}

Considering the profile of the company's activity and its range, the cash benefits that are collected by the state and local government units often largely contribute to the financing and implementation of public undertakings. Money collected as a tax, paid in the communes in which the enterprise carries out its business activity, contributes to (among others) the development of infrastructure, health care and education. The total amount of tax consists of property taxes, excise tax, VAT, income taxes on salaries and corporate income tax. In the years 2013-2017, PGE on average allocated EUR 1.2 billion on tax liabilities (Table 3). This translated into the support for local budgets at the level of approx. EUR 120 million in 2013-2014 and on average EUR 160 million in 2015-2017. As a result of the group's activities, the local governments received EUR 168 million in 2015, which constituted $14.2 \%$ of the total amount of taxes. As a result of its business activity, the group allocated almost EUR 1.4 billion on taxes in 2013, i.e. the most in the analyzed period, however this translated into the lowest support for local budgets, i.e. 8.3\% of the total amount. Table 3 presents the estimated list of cash benefits of the PGE Group in 2013-2017. It should be noted that in 2013 in the Bełchatów commune, which is the seat of PGE GiEK SA, over $60 \%$ of local government expenditure was financed thanks to the taxes paid by GK PGE (http://raportyspoleczne.pl/). The Kleszczów commune, which is characterized by the 
highest budgetary income per capita (http://stat.gov.pl/), financed over $50 \%$ of local government expenditure from the tax liabilities of the PGE Group in 2015 (http://raportzintegrowany2016. gkpge.pl/).

TABLE 3. Cash benefits paid by PGE SA at the individual levels

TABELA 3. Świadczenia pieniężne odprowadzane przez GK PGE na poszczególnych szczeblach

\begin{tabular}{|c|c|c|c|c|c|c|}
\hline \multicolumn{7}{|c|}{ Share of cash benefits at the individual levels } \\
\hline & & 2013 & 2014 & 2015 & 2016 & 2017 \\
\hline Central level & treasury & $73.79 \%$ & $77.11 \%$ & $64.21 \%$ & $63.95 \%$ & $67.10 \%$ \\
\hline Internal company level & social security & $17.91 \%$ & $13.66 \%$ & $21.59 \%$ & $22.45 \%$ & $20.30 \%$ \\
\hline \multirow{3}{*}{ Local level } & commune budgets & $6.07 \%$ & $6.35 \%$ & $6.97 \%$ & $7.22 \%$ & $6.43 \%$ \\
\hline & county budgets & $0.82 \%$ & $0.84 \%$ & $0.91 \%$ & $0.94 \%$ & $0.89 \%$ \\
\hline & provincial budgets & $1.42 \%$ & $2.04 \%$ & $6.32 \%$ & $5.45 \%$ & $5.28 \%$ \\
\hline \multicolumn{2}{|l|}{ Total [billion EUR] } & 1.42 & 1.33 & 1.17 & 1.13 & 1.24 \\
\hline
\end{tabular}

Source: own study based on the company's financial statements from the years 2013-2017.

\section{Costs of employee benefits and social services fund assets}

During the years 2013-2017, PGE SA employed an average of 40,000 employees in all segments of its activity (Table 4). The highest level of employment concerns the Conventional Energy segment, in which the main pillar is PGE GiEK SA. Analyzing the available PGE SA documents of enabled the division and specification of two groups of costs included in the elements of the financial statement. One of them is "internal" stakeholders.

In the context of internal stakeholders, the company's social responsibility was, among others, observed in the case of the costs of the employee benefits (Table 5). Their significant percentage consists of costs associated with medical care, trainings, jubilee awards and the Voluntary Redundancy Program, which provides funds for severance pay for employees, who in exchange for voluntary resignation from work receive a higher severance pay. Other items of costs included in the group's financial statements consist of funds allocated for social activity. PGE SA subsidizes activities aimed at loans granted to employees (among others).

The biggest amount of funds for employee related activities was spent by the company in 2014 and it was over EUR 258 million, while in the remaining analyzed years, it amounted to 
TABLE 4. Shaping of employment in PGE SA

Tabela 4. Kształtowanie się zatrudnienia w Grupie Kapitałowej PGE

\begin{tabular}{|l|c|c|c|c|c|}
\hline \multirow{2}{*}{\multicolumn{1}{c|}{ Segment }} & \multicolumn{5}{c|}{ Year } \\
\cline { 2 - 6 } & 2013 & 2014 & 2015 & 2016 & 2017 \\
\hline Conventional Energy Generation & 18,871 & 23,903 & 23,198 & 22,788 & 25,382 \\
\hline Renewable Energy Generation & 584 & 577 & 519 & 509 & 510 \\
\hline Trade & 1,929 & 2,113 & 2,002 & 2,066 & 2,219 \\
\hline Distribution & 10,938 & 10,648 & 10,298 & 10,239 & 10,200 \\
\hline Other consolidated companies & 8,873 & 2,736 & 2,860 & 2,869 & 2,920 \\
\hline Total employment & 41,195 & 39,977 & 38,877 & 38,471 & 41,231 \\
\hline
\end{tabular}

Source: own study based on the company's consolidated reports from the years 2013-2017.

TABLE 5. Costs concerning internal stakeholders

TABELA 5. Koszty dotyczące interesariuszy wewnętrznych

\begin{tabular}{|c|c|c|c|c|}
\hline \multicolumn{5}{|c|}{ Internal stakeholders [million EUR] } \\
\hline Year & $\begin{array}{c}\text { Loans granted to } \\
\text { employees }\end{array}$ & $\begin{array}{c}\text { Other costs of employee benefits } \\
\text { (health care, trainings, etc.) }\end{array}$ & Jubilee awards & $\begin{array}{c}\text { Voluntary Redundancy } \\
\text { Program }\end{array}$ \\
\hline 2013 & 27.14 & 111.19 & 25.00 & 0.24 \\
\hline 2014 & 25.71 & 113.10 & 23.81 & 96.19 \\
\hline 2015 & 22.86 & 112.14 & 47.38 & - \\
\hline 2016 & 21.67 & 108.81 & 24.29 & 3.81 \\
\hline 2017 & 21.19 & 108.10 & 25.00 & 0.48 \\
\hline
\end{tabular}

Source: own study based on the company's consolidated reports from the years 2013-2017.

approx. EUR 166 million. With respect to profit before tax, which is a good measure of the financial condition of an entity's operations, these expenses, on average, amounted to 9\% EBITDA. In 2014, the share of social costs was the highest in relation to EBIDTA and it amounted to $13.4 \%$ (Fig. 2). 


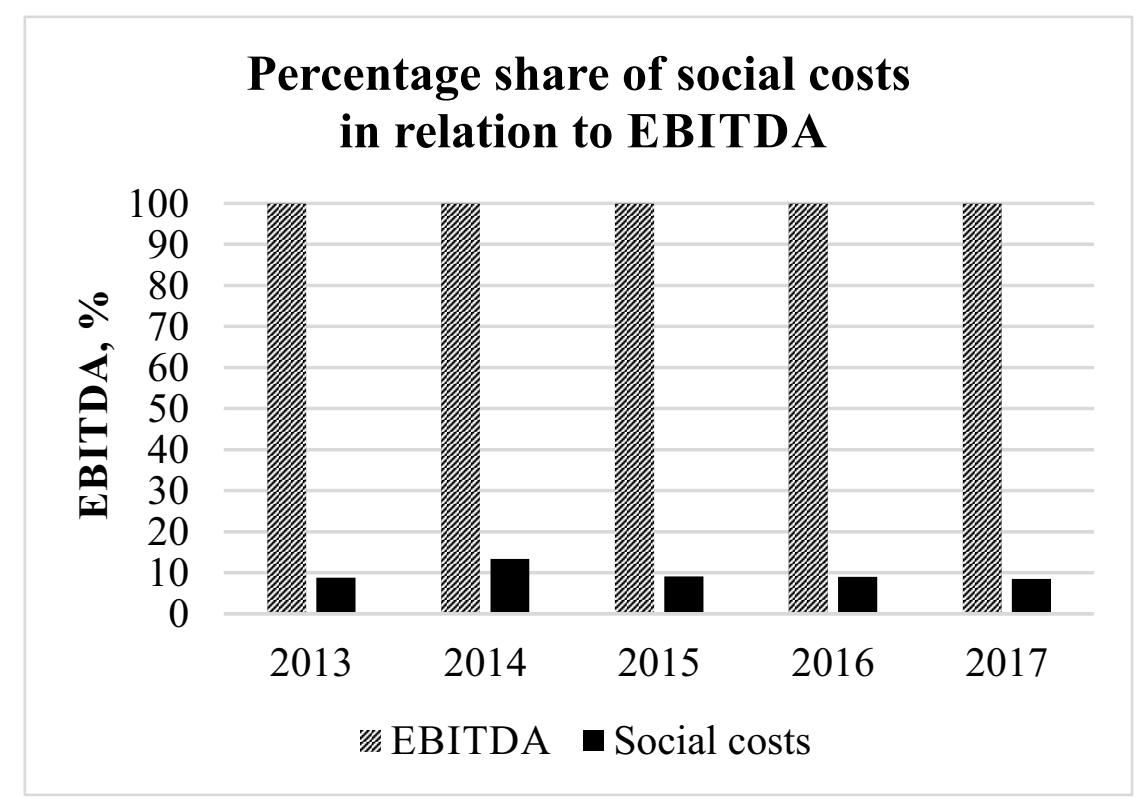

Fig. 2. Share of social costs in relation to EBITDA

(own study based on the company's reports from the years 2013-2017)

Rys. 2. Udział kosztów społecznych w odniesieniu do EBITDA

\section{Environmental costs}

The second of the specified groups of costs included in the elements of the financial statements of PGE SA are environmental costs i.e. emission costs or fines for exceeding emissions. The natural environment is a key factor of life, as well as economic development. Environmental costs are the costs incurred by enterprises as part of the compensation associated with the negative impact of business activity on the ecosystem. These are the costs incurred in the framework of environmental protection and the use of natural resources.

One of the imposed methods of reducing pollution are environmental costs expressed in $\mathrm{CO}_{2}$ emission allowances, the so-called EUA are the rights to emission allocated to EU countries (Jurdziak and Wiktorowicz 2007; Stala-Szlugaj and Grudziński 2017). If the actual emission exceeds the allocated allowances, they must be purchased. This certificate allows for the controlled trade in emissions. PGE SA creates reserves for liabilities associated with $\mathrm{CO}_{2}$ emissions. They are related to the allowances granted free of charge, based on the investment outlays listed in the National Investment Plan. Table 6 shows the monetary value of the level of reserves, their use, as well as the establishment of new reserves in the years 2013-2017. 
TABLE 6. List of the amounts of reserves for the shortage of $\mathrm{CO}_{2}$ emission allowances

TABELA 6. Zestawienie wartości rezerw na niedobór uprawnień do emisji $\mathrm{CO}_{2}$

\begin{tabular}{|c|c|c|c|}
\hline \multicolumn{4}{|c|}{ Value of reserves for the shortage of $\mathrm{CO}_{2}$ emission allowances [million EUR] } \\
\hline Year & Reserve amount & Used reserves & Created reserves \\
\hline 2013 & 341 & 38 & 340 \\
\hline 2014 & 161 & 162 & 161 \\
\hline 2015 & 181 & 162 & 182 \\
\hline 2016 & 275 & 181 & 275 \\
\hline 2017 & 346 & 275 & 287 \\
\hline
\end{tabular}

Source: own study based on the company's consolidated reports from the years 2013-2017.

Other costs that can be classified as environmental costs are costs associated with the reclamation. Future costs of reclamation and development of post-mining areas are estimated on the basis of the anticipated costs of revitalization works, and the level of reclamation reserves is determined based on them. The Group creates reserves for reclamation (Table 7) of two mines, i.e. KWB Bełchatów and KWB Turów, which will be subject to revitalization in the years 2023-2087. The reclamation costs also include the legally regulated Mine Liquidation Fund, which is created according to the national Act - Geological and Mining Law (Journal of Laws of 2019, item 868). Another part of the reclamation reserves consists of ash dumps, generated during the process of electricity production. The amount of costs of the reserves is estimated based on the degree of dump filling. Another part of the reclamation reserves consists of costs associated with the revitalization of wind farm areas. In this case, the costs necessary for the dismantling and removal equipment as well as structures, and restoring the land to its original condition, are estimated. The values of individual components of the reclamation reserves in the years 2013-2017 are demonstrated in the table below (Table 7).

TABLE 7. Value of reclamation reserves

TABELA 7. Wartość rezerw rekultywacyjnych

\begin{tabular}{|c|c|c|c|c|c|}
\hline \multicolumn{7}{|c|}{ Reclamation reserves [million EUR] } \\
\hline Year & $\begin{array}{c}\text { Reclamation of mining } \\
\text { excavations }\end{array}$ & Ash dumps & $\begin{array}{c}\text { Post-wind farm } \\
\text { areas }\end{array}$ & $\begin{array}{c}\text { Costs of the liquidation } \\
\text { of tangible fixed assets }\end{array}$ & Total \\
\hline 2013 & 526 & 15 & 20 & 15 & 577 \\
\hline 2014 & 725 & 22 & 27 & 10 & 785 \\
\hline 2015 & 726 & 23 & 12 & 36 & 798 \\
\hline 2016 & 563 & 23 & 12 & 39 & 636 \\
\hline 2017 & 641 & 42 & 13 & & 735 \\
\hline
\end{tabular}

Source: own study based on the company's consolidated reports from the years 2013-2017. 
By analyzing the above table, it can be noticed that the biggest share in the total of reclamation reserves is demonstrated for those associated with the revitalization of mining excavations. On average, they represent $90 \%$ of all reserves in the analyzed period of time. This is associated with the enormous amount of works that must be carried out in the reclamation process, starting from shallowing of excavations and ending with the development.

Environmental costs also include penalties imposed on the company for non-compliance with legal standards and principles of environmental protection. PGE is an enterprise that has a strong negative impact on the neighboring environment due to the specificity of the fuel and energy industry. However, taking the scope of the company's activity into account, it can be concluded that the imposed penalties are not very high in relation to the group's cash flows and profits (Table 8), which is also a manifestation of the entity's care for the environment.

TABLE 8. Level of environmental penalties imposed on PGE

TABela 8. Poziom kar środowiskowych nakładanych na PGE

\begin{tabular}{|c|c|c|}
\hline Year & Environmental penalties [EUR] & EBITDA [million EUR] \\
\hline 2013 & $6,124.52$ & $1,865.95$ \\
\hline 2014 & 119.05 & $1,932.86$ \\
\hline 2015 & - & $1,959.05$ \\
\hline 2016 & $1,217.86$ & $1,756.19$ \\
\hline 2017 & $7,886.55$ & $1,821.43$ \\
\hline
\end{tabular}

Source: own study based on the company's consolidated reports from the years 2013-2017.

These include sanctions associated with the exceeding of noise standards in mines, emissions of substances, as well as non-compliance with the legal conditions. E.g. in 2017, the Łódź Inspector of Environmental Protection imposed a penalty on PGE Dystrybucja as a result of non-compliance with the conditions of permit required by the Water Law Act. They also include administrative errors, such as the untimely and incorrect keeping of waste records.

\section{Conclusion}

Corporate social responsibility constitutes a challenge for small, as well as large companies. Environmental awareness in Poland increases year by year, and the companies that want to distinguish themselves among the competition must implement CSR activities in their strategies. A new broader view of the CSR concept was born in the $20^{\text {th }}$ century. In order to implement it, the long-term work and commitment of the company, as well as its stakeholders, are necessary. 
The purpose of this research work was to perform the budgetary analysis of the selected GK PGE SA in terms of corporate social responsibility activities and the identification of these activities in relation to their recipients. Moreover, it included the estimation of the level of expenditure based on available consolidated financial statements, disclosed reports, as well as distributed data and information sources.

In the years 2013-2017, the achievements of GK PGE SA in the scope of relations with stakeholders are satisfactory. The company tries to engage each group of its business line by creating many projects in various functional areas. Employees, customers, local community, as well as the silent stakeholder - natural environment, can count on a number of campaigns implemented by the company as part of a long-term partnership policy. However, these are not only activities focused on achieving benefits in the scope of public relations and taking care of a good image. These undertakings have a strong impact on the potential recipients. E.g. the customers can count on a number of facilities associated with the awareness of purchasing products and services, as well as support activities. It can be concluded that the company is characterized by quite a high awareness in regard to CSR, which will allow it to benefit from assumed business strategy and to achieve business goals in the future.

In the financial aspect, the pillar and the most recognizable point of PGE SA activity in the scope of CSR is undoubtedly the PGE Foundation. Members of the PGE group systematically subsidize the foundation, allowing it to implement its goals. Stable support at a similar level was noted in the analysed period. Certain deviations can be noticed in 2015 and 2016, in which a significant increase (2015) and decrease (2016) of the foundation's subsidy level were observed. Although taxes are not directly related to CSR, it should be noted that their size allows for the local development of communes, counties and provinces to which they are paid. Often, over half of the investments are financed from the tax liabilities of the PGE Group.

The identification of costs in the framework of socio-environmental initiatives, based on the entity's available documents, enabled the level of costs related to the internal stakeholders and environmental issues to be illustrated. Activities associated with internal stakeholders include loans, employee benefits (health care, trainings), jubilee awards and a voluntary redundancy program. Within the analyzed years, the company allocated an average of $9 \%$ of its operating profit before tax to them, which amounted to approximately EUR 166 million. Environmental costs, which the Group presents in its statements as reserves, are $\mathrm{CO}_{2}$ emission allowances and the costs of future reclamation, which include the reclamation of excavations, ash dumps and post-wind farm areas. The the costs of reclamation of mining excavations constitute the largest percentage of costs.

In conclusion, the idea of social responsibility in Poland is quite new and only large enterprises make the efforts to try and operate in accordance with this strategy (formal requirements). Undoubtedly, the vertically integrated company that is discussed in this article is a good example of these activities, and its actions in the scope of CSR can constitute a set of good practices for other entities, not only those operating in the same sector. 


\section{References}

ACT - Geological and Mining Law (Journal of Laws of 2019, item 868).

Alves et al. 2019 - Alves, W., Ferreira, P. and Araúso, M. 2019. Mining co-operatives: A model to establish a network for sustainability. Journal of Co-operative Organization and Management 7(1), pp. $51-63$.

Anuszkiewicz, K. and Marona, T. 2012. The role of stakeholders in the development of the socially responsible company (Rola interesariuszy w rozwoju przedsiębiorstwa odpowiedzialnego spolecznie). Rynek - Spoleczeństwo - Kultura No. 1, pp. 34-41 (in Polish).

Arond et al. 2019 - Arond, E., Bebbington, A. and Dammert, J.L. 2019. NGOs as innovators in extractive industry governance. Insights from the EITI process in Colombia and Peru. The Extractive Industries and Society 6(3), pp. 665-674.

Bąk, P. and MichalaK, A. 2018. The problem of managers' remuneration in state-owned enterprises in the context of corporate governance. Gospodarka Surowcami Mineralnymi-Mineral Resources Management Vol. 34, Iss. 1, pp. 155-174.

Bluszcz, A. and KiJewsKa, A. 2015. Challenges of sustainable development in the mining and metallurgy sector in Poland. Metalurgija 54(2), pp. 441-444.

Bogacz, P. and Migza, M. 2016. Environmental management reporting in Polish mining companies in the context of World CSR trends. $1^{\text {st }}$ International Conference on the Sustainable Energy and Environment Development (SEED 2016), E3S Web Conferences, Vol. 10, DOI: 10.1051/e3sconf $/ 20161000058$

Bowen, H. 1953. Social responsibilities of the businessman. New York: Harper, 276 pp.

Chen et al. 2018 - Chen, Y.C., Hung, M. and WAng, Y. 2018. The effect of mandatory CSR disclosure on firm profitability and social externalities: Evidence from China. Journal of Accounting and Economics 65(1), pp. 169-190.

Clarkson, M. 1995. A stakeholder framework for analyzing and evaluating corporate social performance. Academy of Management Review 20(1), pp. 92-117.

Devenin, V. and BiAnCHI, C. 2018. Soccer fields? What for? Effectiveness of corporate social responsibility initiatives in the mining industry. Corporate Social Responsibility and Environmental Management 25(5), pp. 866-879.

Dobele et al. 2014 - Dobele, A., Westberg, K., Steel, M. and flowers, K. 2014. An examination of corporate social responsibility implementation and stakeholder engagement: A case study in the Australian mining industry. Business Strategy and the Environment 23(3), pp. 145-159.

Dong et al. 2014 - Dong, S., Burritt, R. and Qian, W. 2014. Salient stakeholders in corporate social responsibility reporting by Chinese mining and minerals companies. Journal of Cleaner Production 84, pp. 59-69.

European Commision 2010. Doc. 3. Europe 2020. A European strategy for smart, sustainable and inclusive growth (Strategia na rzecz inteligentnego i zrównoważonego rozwoju sprzyjajacego wtaczeniu spolecznemu “Europa 2020”). Brussels, DOI: 10.14746/rie.2010.4.22 (in Polish).

EweJe, G. and Palakshappa, N. 2009. Business partnerships with non-profits: Working to solve mutual problems in New Zealand. Corporate Social Responsibility and Environmental Management 16(6), pp. 337-351, DOI: 10.1002/csr.192.

Freeman, R. 1984. Strategic Management: A stakeholder Approach. Boston, MA: Pittman, 276 pp.

Govindan et al. 2014 - Govindan, K., Kannan, D. and Shankar, K.M. 2014. Evaluating the drivers of corporate social responsibility in the mining industry with multi-criteria approach: a multi-stakeholder perspective. J. Clean. Prod. 84 (0), pp. 214-232, DOI: 10.1016/j.jclepro.2013.12.065. 
GREEN PAPER, 2001. GREEN PAPER Promoting a European framework for Corporate Social Responsibility.

HAMANN, R. 2003. Mining companies' role in sustainable development: The 'why' and 'how' of corporate social responsibility from a business perspective. Development Southern Africa 20(2), pp. 237-254.

HĄBEK et al. 2019 - HąBeK, P., BiAly, W. and Livenskaya, G. 2019. Stakeholder engagement in corporate social responsibility reporting. The case of mining companies. Acta Montanistica Slovaca 24(1), pp. $25-34$.

JAmali, D. and KeShishian, T. 2009. Uneasy alliances: Lessons learned from partnerships between businesses and NGOs in the context of CSR. Journal of business Ethics 84(2), pp. 277-295.

JAROSLAWSKA-SOBÓR, S. 2015. Social potential growth of a mining company on the basis of human capital and occupational safety. Journal of Sustainable Mining 14(4), pp. 195-202.

Jenkins, H. and Yakovleva, N. 2006. Corporate social responsibility in the mining industry: Exploring trends in social and environmental disclosure. Journal of cleaner production 14(3-4), pp. 271-284.

JONEK-KOWALSKA, I. 2018. How do turbulent sectoral conditions sector influence the value of coal mining enterprises? Perspectives from the Central-Eastern Europe coal mining industry. Resources Policy 55, pp. 103-112.

JONEK-KOWALSKA, I. 2019. Consolidation as a risk management method in the lifecycle of a mining company: A novel methodological approach and evidence from the coal industry in Poland. Resources Policy 60, pp. 169-177.

JuRDZIAK, L. and WiKTOROWICZ, J. 2007. Elements of risk analysis during evaluation of profitability of energy production from lignite (Elementy analizy ryzyka przy ocenie opłacalności produkcji energii elektrycznej z węgla brunatnego). Gospodarka Surowcami Mineralnymi-Mineral Resources Management Vol. 23, Special Iss. 2, pp. 131-150 (in Polish).

Kemp et al. 2012 - Kemp, D., Owen, J.R. and Van De GraAfF, S. 2012. Corporate social responsibility, mining and "audit culture". Journal of Cleaner Production 24, pp. 1-10.

KRAWCZYK, P. 2019. CSR Reporting Standards: Implementation in Polish Enterprises. Journal of Eastern Europe Research in Business and Economics Vol. 2019, DOI: 10.5171/2019.247075.

LodHia, S. and Hess, N. 2014. Sustainability accounting and reporting in the mining industry: current literature and directions for future research. Journal of Cleaner Production 84, pp. 43-50.

Managements Board report on activities of PGE Capital Group for 2013 (2014, 2015, 2016, 2017) (Sprawozdanie Zarzadu z działalności Grupy Kapitałowej PGE Polska Grupa Energetyczna SA za rok 2013 (2014, 2015, 2016, 2017)) (in Polish).

Manowska et al. 2017 - Manowska, A., Osadnik, K.T. and Wyganowska, M. 2017. Economic and social aspects of restructuring Polish coal mining: Focusing on Poland and the EU. Resources Policy 52, pp. 192-200.

Morsing, M. and Schultz, M. 2006. Corporate social responsibility communication: stakeholder information, response and involvement strategies. Business ethics: a European review 15(4), pp. 323-338.

Mutti et al. 2012 - Mutti, D., Yakovleva, N., VazQuez-Brust, D. and Di Marco, M.H. 2012. Corporate social responsibility in the mining industry: Perspectives from stakeholder groups in Argentina. Resources Policy 37(2), pp. 212-222.

[Online] www.odpowiedzialnybiznes.pl [Accessed: 2019-01-08].

[Online] www.respectindex.pl [Accessed: 2019-06-15].

Pactwa, K. 2019a. Is There a Place for Women in the Polish Mines? Selected Issues in the Context of Sustainable Development. Sustainability 11(9), 2511, DOI: 10.3390/su11092511.

PACTWA, K. 2019b. Scope of implementation of sustainable development goals by the mining sector in Poland. ISBN 978-83-951536-3-1 Copyright by Faculty of Geoengineering, Mining and Geology Wrocław University of Science and Technology (in Polish). 
Pactwa, K. and WoźNiaK, J. 2017. Environmental reporting policy of the mining industry leaders in Poland. Resources Policy Vol. 53(C), pp. 201-207, DOI: 10.1016/j.resourpol.2017.06.008.

PGE Dystrybucja SA. [Online] https://pgedystrybucja.pl/ [Accessed: 2019-11-15].

PGE Energia Ciepła SA. [Online] https://pgeenergiaciepla.pl/ [Accessed: 2019-11-15].

PGE Energia Odnawialna SA. [Online] https://pgeeo.pl/ [Accessed: 2019-11-15].

PGE Górnictwo i Energetyka SA. [Online] https://pgegiek.pl [Accessed: 2019-11-15].

PGE Obrót SA. [Online] https://pge-obrot.pl/ [Accessed: 2019-11-15].

Que et al. 2018 - Que, S., Wang, L., Awuah-Offei, K., Chen, Y. and Yang, W. 2018. The status of the local community in mining sustainable development beyond the triple bottom line. Sustainability 10(6), DOI: $10.3390 /$ su10061749.

Que et al. 2019 - Que, S., Wang, L., Awuah-OfFei, K., YAnG, W. and Jiang, H. 2019. Corporate Social Responsibility: Understanding the Mining Stakeholder with a Case Study. Sustainability 11(8), DOI: $10.3390 /$ su11082407.

RESPECT Index. [Online] http://respectindex.pl/ [Accessed: 2019-11-15].

Social Report GK PGE 2013-2014 (Raport Spoleczny GK PGE 2013-2014). [Online] http://raportyspoleczne.pl/wp-content/uploads/raports/ceadbf90bcc10ae36770f0081bf30b0f.pdf [Accessed: 2019-01-05] (in Polish).

Sustainability Report GK PGE 2016 (Raport zrównoważony PGE, 2016). [Online] http://raportzintegrowany2016.gkpge.pl/pl/partnerstwo/spolecznosci-lokalne/podatki-i-oplaty [Accessed: 2019-01-05] (in Polish).

STALA-SZLUGAJ, K. and GRUDZIŃSKI, Z. 2017. Environmental costs resulting from the use of hard coal to electricity generation in Poland. In E3S Web of Conferences Vol. 19, DOI: 10.1051/e3sconf/20171902023.

Statistical Offices. [Online] http://stat.gov.p1/ [Accessed: 2019-01-05].

SzEWCZAK, J. 2019. Budget analysis of a selected mining company towards corporate social responsibility (CSR) (Analiza budżetowa podmiotu górniczego pod kątem działań w zakresie społecznej odpowiedzialności biznesu (CSR)). Politechnika Wrocławska (in Polish).

The consolidated financial statements of the Capital Group of PGE Polska Grupa Energetyczna SA for the year 2013 (2014, 2015, 2016, 2017) (PGE Polska Grupa Energetyczna SA. Skonsolidowane sprawozdanie finansowe za rok 2013 (2014, 2015, 2016, 2017)) (in Polish).

Viveros, H. 2016. Examining stakeholders' perceptions of mining impacts and corporate social responsibility. Corporate Social Responsibility and Environmental Management 23(1), pp. 50-64.

VIVEROS, H. 2017. Unpacking stakeholder mechanisms to influence corporate social responsibility in the mining sector. Resources Policy 51, pp. 1-12, DOI: 10.1016/j.resourpol.2016.10.014.

WACHOWIAK, P. 2012. How to conduct a dialogue with stakeholders? (Jak prowadzić dialog z interesariuszami?) E-mentor nr 1 (43) (in Polish).

Witek-Crabb, A. 2019. CSR Maturity in Polish Listed Companies: A Qualitative Diagnosis Based on a Progression Model. Sustainability 11(6), DOI: 10.3390/su11061736.

WoŹNIAK, J. 2019. The role and implementation of the concept of social responsibility in the functioning of mining and energy industry (Rola i implementacja koncepcji spolecznej odpowiedzialności w funkcjonowaniu branży wydobywczej i energetycznej). Wrocław: Wydział Geoinżynierii, Górnictwa i Geologii Politechniki Wrocławskiej (in Polish).

WoźNIAK, J. and JuRCZYK, W. 2019. Social And Environmental Activities In The Polish Mining Region In The Context Of CSR, Resources Policy 65, DOI: 10.1016/j.resourpol.2019.101554.

Yakovleva, N. and VAZqueZ-Brust, D. 2012. Stakeholder perspectives on CSR of mining MNCs in Argentina. Journal of Business Ethics 106, pp. 191-211. 


\section{Inicjatywy CSR w zintegrowanym podmiocie energetycznym - wymiar pieniężny}

\section{Streszczenie}

Temat artykułu dotyczy rosnącego problemu wdrażania koncepcji społecznej odpowiedzialności w działaniach zintegrowanego podmiotu energetycznego. Praca ta obejmuje wykonanie analizy budżetowej wiodącej firmy krajowej pod względem wydatków związanych z odpowiedzialnością społeczną przedsiębiorstw (CSR). W artykule dokonano analizy literatury źródłowej oraz identyfikacji działań interesariuszy. Wprowadzenie zawiera wyjaśnienie koncepcji CSR, jej globalnego podejścia wraz z uzasadnieniem konieczności wdrożenia koncepcji CSR w strategii podmiotów branżowych. Do przeprowadzenia badania wykorzystano między innymi: elementy sprawozdawczości finansowej i niefinansowej, tj. raporty pionowo zintegrowanej spółki energetycznej - Grupy Kapitałowej Polska Grupa Energetyczna SA (GK PGE SA), w latach 2013-2017. Wykorzystano dane uzyskane ze źródeł rozproszonych. Zidentyfikowano działania firmy w kierunkach społecznych i środowiskowych, określono grupy interesariuszy tych inicjatyw oraz zakres dobrych praktyk dla nich. Głównym celem tego artykułu było oszacowanie poziomu wydatków związanych z CSR w kontekście budżetu ogólnego firmy. W artykule podkreślono rolę Fundacji PGE jako rozpoznawalnego punktu działalności firmy w zakresie CSR (zaprezentowano udział poszczególnych firm grupy w finansowaniu fundacji). W przeprowadzonej analizie wydatków CSR uwzględniono między innymi: wysokość płaconych podatków, koszty świadczeń pracowniczych i aktywów funduszu usług społecznych oraz koszty środowiskowe.

SŁowA KLUCZOWE: społeczna odpowiedzialność biznesu (CSR), analiza budżetowa, zintegrowany podmiot energetyczny 
